\title{
Comparison of mechanisms mediating uptake and efflux of thyroid hormones in the human choriocarcinoma cell line, JAR
}

\author{
A M Mitchell ${ }^{1}$, K A Rowan ${ }^{1}$, S W Manley ${ }^{2}$ and R H Mortimer ${ }^{1,3}$ \\ ${ }^{1}$ Conjoint Endocrine Laboratory, Royal Brisbane Hospital, Herston Road, Brisbane, Queensland 4029, Australia \\ ${ }^{2}$ Department of Physiology and Pharmacology, The University of Queensland, Queensland 4072, Australia \\ ${ }^{3}$ Department of Obstetrics and Gynaecology, The University of Queensland, Queensland 4072, Australia \\ (Requests for offprints should be addressed to A M Mitchell)
}

\begin{abstract}
We compared the specificities of transport mechanisms for uptake and efflux of thyroid hormones in cells of the human choriocarcinoma cell line, JAR, to determine whether triiodothyronine $\left(\mathrm{T}_{3}\right)$, thyroxine $\left(\mathrm{T}_{4}\right)$ and reverse $\mathrm{T}_{3}\left(\mathrm{rT}_{3}\right)$ are carried by the same transport mechanism. Uptake of ${ }^{125} \mathrm{I}_{-} \mathrm{T}_{3},{ }^{125} \mathrm{I}_{-} \mathrm{T}_{4}$ and ${ }^{125} \mathrm{I}-\mathrm{rT} \mathrm{T}_{3}$ was saturable and stereospecific, but not specific for $\mathrm{T}_{3}, \mathrm{~T}_{4}$ and $\mathrm{rT}_{3}$, as unlabelled $\mathrm{L}$-stereoisomers of the thyroid hormones inhibited uptake of each of the radiolabelled hormones. Efflux of ${ }^{125} \mathrm{I}_{-} \mathrm{T}_{3}$ was also saturable and stereospecific and was inhibited by $\mathrm{T}_{4}$ and $\mathrm{rT}_{3}$. Efflux of ${ }^{125} \mathrm{I}_{-} \mathrm{T}_{4}$ or ${ }^{125} \mathrm{I}_{-\mathrm{rT}} \mathrm{T}_{3}$ was, in contrast, not significantly inhibited by any of the unlabelled thyroid hormones tested. A range of compounds known to interfere with receptor-mediated thyroid hormone uptake in cells inhibited uptake of ${ }^{125} \mathrm{I}_{-} \mathrm{T}_{3}$
\end{abstract}

and ${ }^{125} \mathrm{I}_{\mathrm{rT}} \mathrm{T}_{3}$, but not ${ }^{125} \mathrm{I}_{-} \mathrm{T}_{4}$. We conclude that in JAR cells uptake and efflux of ${ }^{125} \mathrm{I}_{-} \mathrm{T}_{3}$ are mediated by saturable and stereospecific membrane transport processes. In contrast, the uptake, but not the efflux, of ${ }^{125} \mathrm{I}_{-} \mathrm{T}_{4}$ and ${ }^{125} \mathrm{I}_{-\mathrm{rT}} \mathrm{T}_{3}$ is saturable and stereospecific, indicating that uptake and efflux of $\mathrm{T}_{4}$ and $\mathrm{rT}_{3}$ in JAR cells occur by different mechanisms. These results suggest that in JAR cells thyroid hormones may be transported by at least two types of transporters: a low affinity iodothyronine transporter (Michaelis constant, $K_{\mathrm{m}}$, around $1 \mu \mathrm{M}$ ) which interacts with $\mathrm{T}_{3}, \mathrm{~T}_{4}$ and $\mathrm{rT}_{3}$, but not amino acids, and an amino acid transporter which takes up $\mathrm{T}_{3}$, but not $\mathrm{T}_{4}$ or $\mathrm{rT}_{3}$. Efflux of $\mathrm{T}_{4}$ and $\mathrm{rT}_{3}$ appears to occur by passive diffusion in these cells.

Journal of Endocrinology (1999) 161, 107-113

\section{Introduction}

The degree of thyroid hormone transfer from mother to child remains controversial, although the clinical studies of Vulsma et al. (1989) indicate that, at least in the presence of a hypothyroid fetus, considerable maternal thyroid hormone can reach the fetus. The mechanisms and control of thyroid hormone transfer are, however, as yet undefined.

We have previously described carrier-mediated, saturable membrane transport mechanisms for uptake of triiodothyronine $\left(\mathrm{T}_{3}\right)$ (Mitchell et al. 1992a, 1994) and thyroxine $\left(\mathrm{T}_{4}\right)$ (Mitchell et al. 1995) in the human choriocarcinoma cell line, JAR. These transporters have calculated Michaelis constants $\left(K_{\mathrm{m}}\right)$ of $1 \mu \mathrm{M}$ and $60 \mathrm{nM}$ respectively. The $\mathrm{T}_{3}$ transport mechanism in JAR cells is kinetically similar to that described by us in normal cultured trophoblast cells $\left(K_{\mathrm{m}}=0.8 \mu \mathrm{M}\right.$ (Mitchell et al. 1992b)). In JAR cells, $\mathrm{T}_{3}$ and $\mathrm{T}_{4}$ uptake are both dependent on intracellular energy but independent of the $\mathrm{Na}^{+}$gradient across the cell membrane. The nuclear uptake of $\mathrm{T}_{3}$ in JAR cells is time dependent and accounts

for around $5 \%$ of total cellular uptake after $120 \mathrm{~min}$ of incubation (A M Mitchell, unpublished observations).

Receptor-mediated uptake of thyroid hormones has been described in many types of cells (for recent reviews see Kragie (1994, 1996)). There have been, in contrast, few studies investigating mechanisms of efflux of thyroid hormones from cells (Hennemann et al. 1984, Osty et al. 1990a,b, Samson et al. 1992, Zhou et al. 1992). The finding of saturable efflux processes for thyroid hormones in rat (Osty et al. 1990b, Samson et al. 1992, Zhou et al. 1992) and human (Osty et al. 1990a) erythrocytes raised the possibility that similar saturable efflux processes are present in trophoblasts. These could contribute to the regulation of transplacental transfer of thyroid hormone. We have found evidence in JAR cells that efflux of $T_{3}$ occurs by a saturable process inhibited by external $\mathrm{T}_{3}, \mathrm{~T}_{4}$ and tryptophan (Trp) (Mitchell et al. 1994). We observed a $50 \%$ reduction in the efflux rate of $\mathrm{T}_{3}$ with external $\mathrm{T}_{3}$ and Trp concentrations of around $2 \mu \mathrm{M}$ and $2 \mathrm{mM}$ respectively. It is not known, however, whether uptake and release of thyroid hormones occur in these cells by the same or different transporters. In the present study, we 
compared the specificities of transport mechanisms for uptake and efflux of thyroid hormones in JAR cells to determine whether $T_{3}, T_{4}$ and reverse $T_{3}\left(r T_{3}\right)$ interact with the same transport mechanisms.

\section{Materials and Methods}

\section{Reagents}

Materials were purchased from the following sources: ${ }^{125} \mathrm{I}_{-} \mathrm{T}_{3} \quad(3300 \mu \mathrm{Ci} / \mu \mathrm{g}), \quad{ }^{125} \mathrm{I}_{-} \mathrm{rT}_{3} \quad(790-1250 \mu \mathrm{Ci} / \mu \mathrm{g})$ and ${ }^{125} \mathrm{I}_{-} \mathrm{T}_{4}(1250 \mu \mathrm{Ci} / \mu \mathrm{g})$ from Du Pont Company, Wilmington, DE, USA; fetal calf serum from Commonwealth Serum Laboratories, Melbourne, Victoria, Australia; bicinchoninic acid (BCA) Protein Reagent from Pierce Chemicals, Rockford, IL, USA; six-well tissue culture plates from Costar, Cambridge, MA, USA. All other chemicals and cell culture media were from Sigma Chemical Co., St Louis, MO, USA. Nitrofen was a gift from Rohm and Haas Company, Philadelphia, PA, USA and nitrendipine was a gift from Bayer Pharmaceutical Division, West Haven, CO, USA.

\section{Cell culture}

The JAR cell line was purchased from American Type Culture Collection, Rockville, MD, USA and maintained in continuous culture at $37^{\circ} \mathrm{C}$ in a humidified atmosphere of $95 \%$ air and $5 \% \mathrm{CO}_{2}$. Culture medium was RPMI 1640 supplemented with $10 \%$ (v/v) fetal calf serum. Cells were subcultured three times a week. For uptake and efflux experiments, $3 \times 10^{5}$ cells were plated into each well of the six-well tissue culture plates. Medium was changed $24 \mathrm{~h}$ after plating. Cells were cultured for 2-3 days. At the end of the uptake and efflux experiments, viability of the cells was assessed by the trypan blue exclusion test and was always over 90\%.

\section{Uptake and efflux studies}

The procedures for uptake and efflux studies and the determination of the kinetic parameters $\left(K_{\mathrm{m}}\right.$ and maximum velocity) of initial cellular uptake of ${ }^{125} \mathrm{I}_{-} \mathrm{T}_{3},{ }^{125} \mathrm{I}-\mathrm{T}_{4}$ and ${ }^{125} \mathrm{I}_{-} \mathrm{rT}_{3}$ were as previously described (Mitchell et al. 1994, 1995). Briefly, prior to all uptake experiments cells were incubated for $1 \mathrm{~h}$ in Hanks' balanced salts solution (HBSS). All incubations were carried out at $37^{\circ} \mathrm{C}$. To terminate uptake, incubation medium was aspirated, cells were washed twice in ice-cold HBSS and immediately lysed in $1 \mathrm{M} \mathrm{NaOH}$. Cell-associated radioactivity was determined by counting the radioactivity in a $\gamma$-counter with a counting efficiency of $84 \% .{ }^{125}$ I-labelled thyroid hormone tracer taken up in the presence of analogue or inhibitor was expressed as a percentage of that taken up in the absence of the analogue or inhibitor. The specificity of the uptake process was examined by incubating the cells for $30 \mathrm{~min}$ in the presence of either $30 \mathrm{pM}{ }^{125} \mathrm{I}_{-} \mathrm{T}_{3}$, $100 \mathrm{pM}{ }^{125} \mathrm{I}_{-} \mathrm{rT}_{3}$ or $50 \mathrm{pM}{ }^{125} \mathrm{I}_{-} \mathrm{T}_{4}$, with or without $10 \mu \mathrm{M}$ excess of unlabelled thyroid hormones, $10 \mathrm{mM}$ Trp or $100 \mu \mathrm{M}$ mefenamic acid, verapamil, nifedipine or nitrendipine. Drugs were dissolved in ethanol and diluted in HBSS. The final concentration of ethanol did not exceed $0 \cdot 4 \%$. This had no effect on cellular uptake of $\mathrm{T}_{3}$, $\mathrm{rT}_{3}$ or $\mathrm{T}_{4}$. To determine the kinetic parameters of uptake, the cells were incubated in the presence of $30 \mathrm{pM}^{125} \mathrm{I}_{-} \mathrm{T}_{3}$, $50 \mathrm{pM}^{125} \mathrm{I}_{-} \mathrm{T}_{4}$ or $100 \mathrm{pM}{ }^{125} \mathrm{I}_{-} \mathrm{rT}_{3}$ and unlabelled $\mathrm{T}_{3}, \mathrm{~T}_{4}$ or $\mathrm{rT}_{3}(0-10 \mu \mathrm{M})$ for $2 \mathrm{~min}$. Results from 12-15 determinations were pooled and data fitted to the MichaelisMenten equation using a non-linear curve-fitting program (GraphPad Prism, GraphPad, San Diego, CA, USA). Inhibition constants $\left(K_{\mathrm{i}}\right)$ were calculated by fitting the data pooled from three to eight determinations to the one-site competition model using non-linear regression by GraphPad Prism software.

The procedure to study efflux was as described previously (Mitchell et al. 1994). Briefly, cells were incubated for $45 \mathrm{~min}$ at $37^{\circ} \mathrm{C}$ with $30 \mathrm{pM}{ }^{125} \mathrm{I}_{-} \mathrm{T}_{3}$ or $50 \mathrm{pM}^{125} \mathrm{I}_{-} \mathrm{T}_{4}$, washed, and then incubated for $30 \mathrm{~min}$ at $37{ }^{\circ} \mathrm{C}$ in non-radioactive medium with or without $10 \mu \mathrm{M}$ unlabelled thyroid hormone analogue, $100 \mu \mathrm{M}$ nitrendipine or $10 \mathrm{mM}$ unlabelled Trp. ${ }^{125}$ I-labelled thyroid hormone tracer released in the presence of an analogue, Trp or nitrendipine during the $30 \mathrm{~min}$ incubation in non-radioactive medium was expressed as a percentage of that released in the absence of the analogue, Trp or nitrendipine.

We sought evidence of metabolism of ${ }^{125} \mathrm{I}-\mathrm{T}_{3},{ }^{125} \mathrm{I}-\mathrm{T}_{4}$ and ${ }^{125} \mathrm{I}_{-} \mathrm{rT}_{3}$ by duplicate cultures of JAR cells during uptake experiments by analysing radioactivity present in the cells and in the medium after incubation with the tracers for $30 \mathrm{~min}$ at $37^{\circ} \mathrm{C}$. Similarly to previous studies, we found only minimal evidence of metabolism of the tracers by the cells.

\section{Determination of the cellular protein content}

The protein content of cell lysates was determined with the BCA reagent, which is a modification of the Biuret reaction, using BSA as a standard.

\section{Statistical analysis}

Statistical analysis was performed by one-way ANOVA followed by multiple comparison of means against a single control (Bonferonni's t-test) using the statistical software package, SigmaStat (Jandel Scientific, San Rafael, CA, USA). Results were expressed as means and standard errors of the mean, $n$ is the number of independent determinations. A probability of $<0.05$ was regarded as significant. 

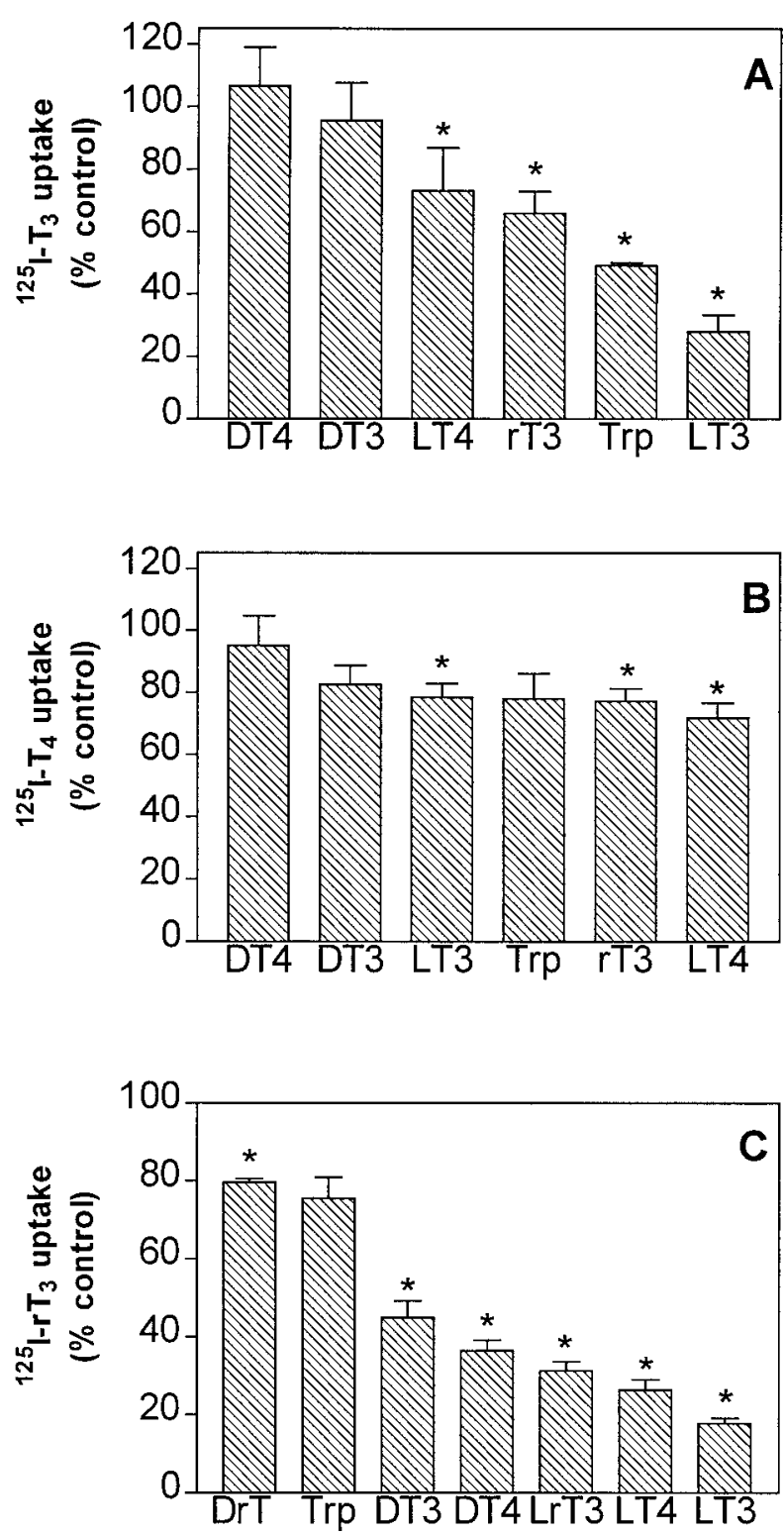

Figure 1 Effect of thyroid hormone analogues on uptake of ${ }^{125} \mathrm{I}-\mathrm{T}_{3}$ (A), ${ }^{125} \mathrm{I}-\mathrm{T}_{4}$ (B) and ${ }^{125} \mathrm{I}-\mathrm{rT}_{3}$ (C) in JAR cells. Cells were incubated for $30 \mathrm{~min}$ at $37^{\circ} \mathrm{C}$ with $30 \mathrm{pM}{ }^{125} \mathrm{I}_{3}, 50 \mathrm{pM}^{125} \mathrm{I}_{4}$ or $100 \mathrm{pM}$ ${ }^{125} \mathrm{I}_{\mathrm{rT}} \mathrm{T}_{3}$ in the absence or in the presence of $10 \mu \mathrm{M}$ unlabelled thyroid hormone analogue, or $10 \mathrm{mM}$ unlabelled Trp. Values shown are means \pm S.E.M. $(n=3-8)$. ${ }^{*} P<0 \cdot 05$.

\section{Results}

The uptake of ${ }^{125} \mathrm{I}_{-} \mathrm{T}_{3},{ }^{125} \mathrm{I}-\mathrm{rT}_{3}$ and ${ }^{125} \mathrm{I}_{-} \mathrm{T}_{4}$ by cultures of JAR cells was saturable. $\mathrm{T}_{3}$ uptake was reduced to $28 \cdot 0 \pm 5 \cdot 4 \%$ of control values $(n=4)$ by an excess of unlabelled $\mathrm{L}_{-} \mathrm{T}_{3}$ (Fig. 1A). $\mathrm{T}_{4}$ uptake was reduced to $71.9 \pm 4.9 \%(n=7)$ by unlabelled $\mathrm{L}^{-\mathrm{T}_{4}}$ (Fig. 1B) and $\mathrm{rT}_{3}$ uptake was reduced by unlabelled $\mathrm{rT}_{3}$ to $31 \cdot 4 \pm 2 \cdot 4 \%$ $(n=3)$ (Fig. 1C).
Uptake of ${ }^{125} \mathrm{I}_{-} \mathrm{T}_{3},{ }^{125} \mathrm{I}_{-} \mathrm{T}_{4}$ and ${ }^{125} \mathrm{I}_{-} \mathrm{rT}_{3}$ was stereospecific, as it was not significantly reduced by a $10 \mu \mathrm{M}$ excess of unlabelled $\mathrm{D}-\mathrm{T}_{3}$ or $\mathrm{D}-\mathrm{T}_{4}$ (Fig. $1 \mathrm{~A}$ and $\mathrm{B}$ ). Unlabelled $\mathrm{D}^{-\mathrm{rT}_{3}}(10 \mu \mathrm{M})$ inhibited only $20 \cdot 4 \pm 1 \cdot 0 \%$ $(n=9)$ of ${ }^{125} \mathrm{I}_{-\mathrm{rT}} \mathrm{F}_{3}$ uptake (Fig. 1C). Unlabelled $\mathrm{L}-$ stereoisomers of thyroid hormones inhibited ${ }^{125} \mathrm{I}_{-} \mathrm{T}_{3}$ uptake (Fig. 1A), ${ }^{125} \mathrm{I}_{-} \mathrm{T}_{4}$ uptake (Fig. 1B) and ${ }^{125} \mathrm{I}_{\mathrm{rT}} \mathrm{r}_{3}$ uptake (Fig. 1C). In the presence of $10 \mathrm{mM}$ unlabelled Trp, or $10 \mu \mathrm{M} \mathrm{L}-\mathrm{rT}_{3}$ or $\mathrm{L}_{-} \mathrm{T}_{4}$, total cellular uptake of ${ }^{125} \mathrm{I}_{-} \mathrm{T}_{3}$ was reduced to $49 \cdot 2 \pm 1 \cdot 0 \%(n=3), 66 \cdot 0 \pm 7 \cdot 1 \%$ $(n=4)$ and $73 \cdot 2 \pm 13 \cdot 9 \%(n=4)$ of control values respectively (Fig. 1A). Similarly, a $10 \mu \mathrm{M}$ excess of unlabelled $\mathrm{L}^{-\mathrm{rT}} \mathrm{T}_{3}$ and $\mathrm{L}-\mathrm{T}_{3}$ reduced total cellular uptake of ${ }^{125} \mathrm{I}-\mathrm{T}_{4}$ to $77 \cdot 2 \pm 4 \cdot 0 \% \quad(n=7)$ and $78 \cdot 5 \pm 4 \cdot 4 \% \quad(n=8)$ (Fig. 1B). Unlabelled $\mathrm{L}_{-} \mathrm{T}_{4}$ and $\mathrm{L}-\mathrm{T}_{3}$ (both $10 \mu \mathrm{M}$ ) reduced total uptake of ${ }^{125} \mathrm{I}_{-\mathrm{rT}}$ to $26 \cdot 4 \pm 2 \cdot 7 \%(n=3)$ and $17 \cdot 8 \pm 1 \cdot 3 \%$ $(n=3)$ respectively (Fig. 1C).

Mefenamic acid, verapamil, nifedipine and nitrendipine (all $100 \mu \mathrm{M}$ ) reduced saturable ${ }^{125} \mathrm{I}_{-} \mathrm{T}_{3}$ uptake to $47 \cdot 8 \pm$ $5 \cdot 8 \%(n=3), 43 \cdot 6 \pm 15 \cdot 8 \%(n=3), 31 \cdot 0 \pm 1 \cdot 8 \%(n=3)$ and $29 \cdot 7 \pm 2 \cdot 1 \%(n=3)$ of control uptake respectively in the absence of inhibitor (Fig. 2A), but failed to inhibit saturable ${ }^{125} \mathrm{I}_{-} \mathrm{T}_{4}$ uptake (Fig. 2B). Verapamil and nifedipine also reduced saturable uptake of ${ }^{125} \mathrm{I}_{\mathrm{rT}} \mathrm{T}_{3}$ to $76 \cdot 8 \pm$ $4 \cdot 3 \%(n=4)$ and $81 \cdot 0 \pm 2 \cdot 6 \%(n=4)$ of control values respectively.

Efflux of ${ }^{125} \mathrm{I}_{-} \mathrm{T}_{3}$ from the cells was inhibited in the presence of unlabelled $\mathrm{L}_{-} \mathrm{T}_{3}$ in the external medium (Fig. 3A), indicating saturability. The amount of ${ }^{125} \mathrm{I}_{-} \mathrm{T}_{3}$ released from the cells during $30 \mathrm{~min}$ incubation in the presence of external unlabelled $\mathrm{L}-\mathrm{T}_{3}(10 \mu \mathrm{M})$ was reduced to $67 \cdot 3 \pm 4 \cdot 2 \%(n=5)$ of that released in the absence of unlabelled $\mathrm{T}_{3}$. Efflux of ${ }^{125} \mathrm{I}_{-} \mathrm{T}_{3}$ was also inhibited by the thyroid hormones and nitrendipine (Fig. 3A), but was not reduced by a $10 \mu \mathrm{M}$ excess of unlabelled $\mathrm{D}^{-\mathrm{T}_{3}}$, indicating that efflux is also stereospecific. In contrast to efflux of ${ }^{125} \mathrm{I}-\mathrm{T}_{3}$, efflux of ${ }^{125} \mathrm{I}-\mathrm{T}_{4}$ from the cells was not significantly affected by any of the unlabelled thyroid hormones tested (Fig. 3B). As was seen for efflux of ${ }^{125} \mathrm{I}_{-} \mathrm{T}_{4}$, but in contrast to efflux of ${ }^{125} \mathrm{I}_{-} \mathrm{T}_{3}$, efflux of ${ }^{125} \mathrm{I}-\mathrm{rT}_{3}$ was not inhibited by a $10 \mu \mathrm{M}$ excess of extracellular unlabelled $\mathrm{rT}_{3}$.

Increasing concentrations of unlabelled $\mathrm{T}_{4}, \mathrm{~T}_{3}$ or $\mathrm{rT}_{3}$ $(0-10 \mu \mathrm{M})$ progressively inhibited the initial rates of specific uptake of ${ }^{125} \mathrm{I}_{-} \mathrm{T}_{3},{ }^{125} \mathrm{I}_{-} \mathrm{T}_{4}$ and ${ }^{125} \mathrm{I}-\mathrm{rT}$ (Fig. 4). The calculated $K_{\mathrm{i}}$ for the inhibition of ${ }^{125} \mathrm{I}^{-} \mathrm{T}_{3}$ uptake by unlabelled $\mathrm{T}_{4}$ and $\mathrm{rT}_{3},{ }^{125} \mathrm{I}_{-} \mathrm{T}_{4}$ uptake by unlabelled $\mathrm{T}_{3}$ and $\mathrm{rT}_{3}$ and ${ }^{125} \mathrm{I}-\mathrm{rT}_{3}$ uptake by unlabelled $\mathrm{T}_{3}$ and $\mathrm{T}_{4}$, and $K_{\mathrm{m}}$ for uptake of ${ }^{125} \mathrm{I}_{-} \mathrm{T}_{3},{ }^{125} \mathrm{I}-\mathrm{T}_{4}$ and ${ }^{125} \mathrm{I}_{-\mathrm{rT}}$ are listed in Table 1.

\section{Discussion}

Although we have previously characterised stereospecific, energy-dependent uptake of $\mathrm{T}_{4}$ and $\mathrm{T}_{3}$ by JAR cells it has not been clear if shared or distinct transporters mediate 

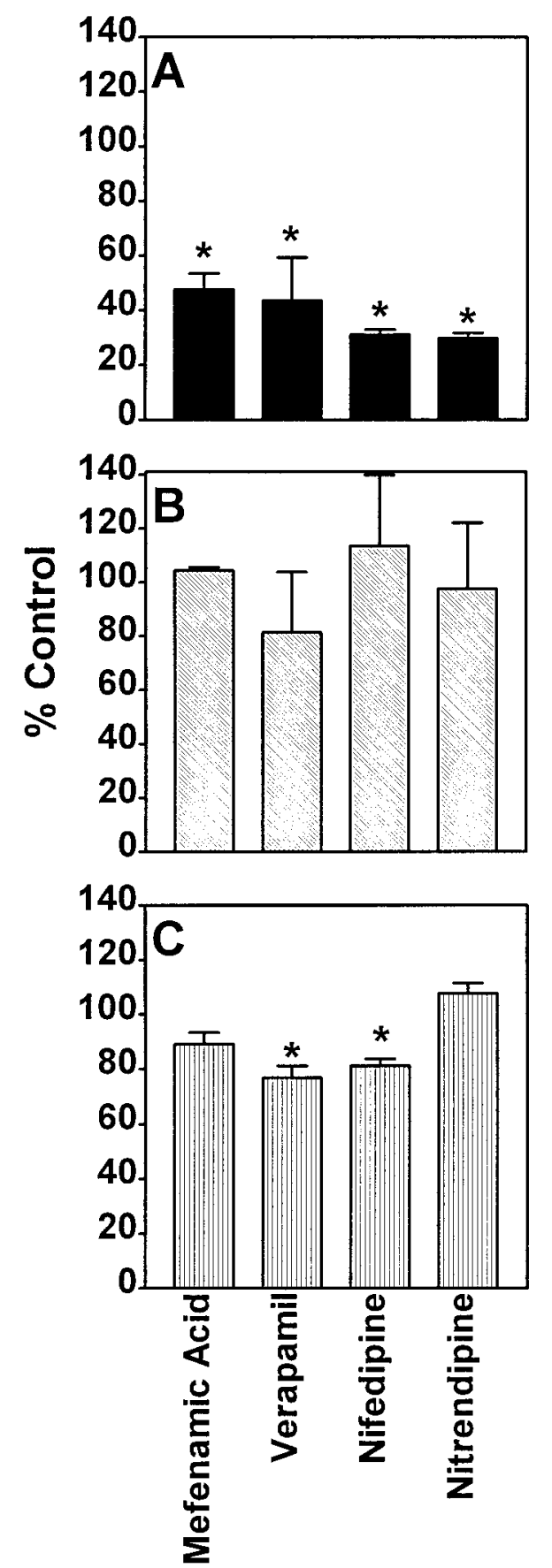

Inhibitors

Figure 2 Effect of various inhibitors on saturable uptake of ${ }^{125} \mathrm{I}-\mathrm{T}_{3}$ (A), ${ }^{125} \mathrm{I}_{-} \mathrm{T}_{4}$ (B) and ${ }^{125} \mathrm{I}-\mathrm{rT} \mathrm{T}_{3}(\mathrm{C})$ in JAR cells. Cells were incubated for 2 min at $37^{\circ} \mathrm{C}$ with $30 \mathrm{pM}^{125} \mathrm{I}_{-} \mathrm{T}_{3}, 50 \mathrm{pM}^{125} \mathrm{I}-\mathrm{T}_{4}$ or $100 \mathrm{pM}$

${ }^{125} \mathrm{I}_{\mathrm{r} \mathrm{T}_{3}}$ in the absence or in the presence of $100 \mu \mathrm{M}$ mefenamic acid, verapamil, nifedipine or nitrendipine. Values are

means \pm S.E.M. $(n=3-4) .{ }^{*} P<0 \cdot 05$.
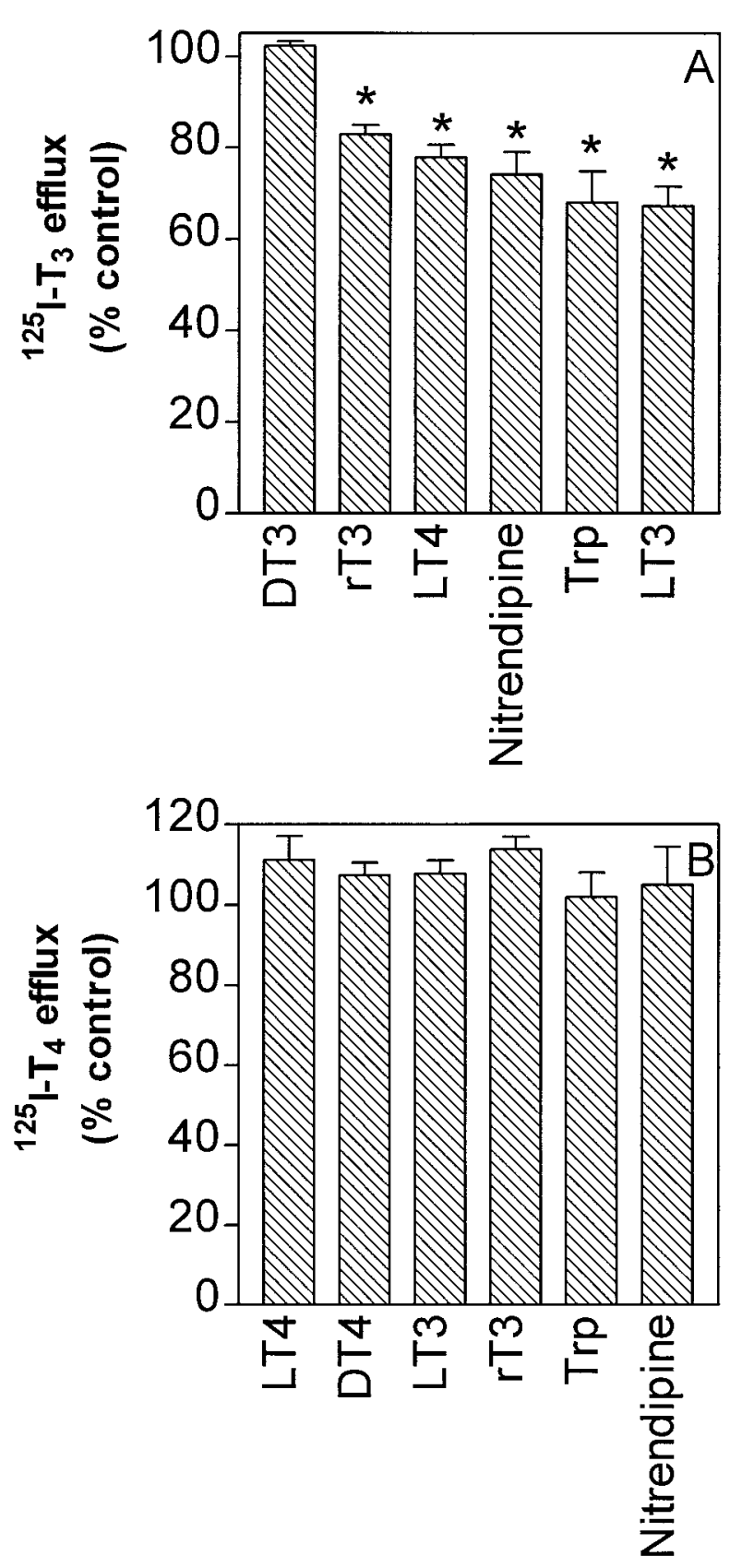

Figure 3 Effect of thyroid hormone analogues on efflux of ${ }^{125} \mathrm{I}_{3}$ and ${ }^{125} \mathrm{I}_{\mathrm{T}}$ from JAR cells. Cells were incubated for $45 \mathrm{~min}$ at $37^{\circ} \mathrm{C}$ with $30 \mathrm{pM}^{125} \mathrm{I}-\mathrm{T}_{3}$ or $50 \mathrm{pM}^{125} \mathrm{I}_{4}$, washed, and then incubated for $30 \mathrm{~min}$ at $37^{\circ} \mathrm{C}$ in non-radioactive medium with or without $10 \mu \mathrm{M}$ unlabelled thyroid hormone analogue, or $10 \mathrm{mM}$ unlabelled Trp. Values shown are means \pm S.E.M. $(n=4-5) .{ }^{*} P<0 \cdot 05$. 

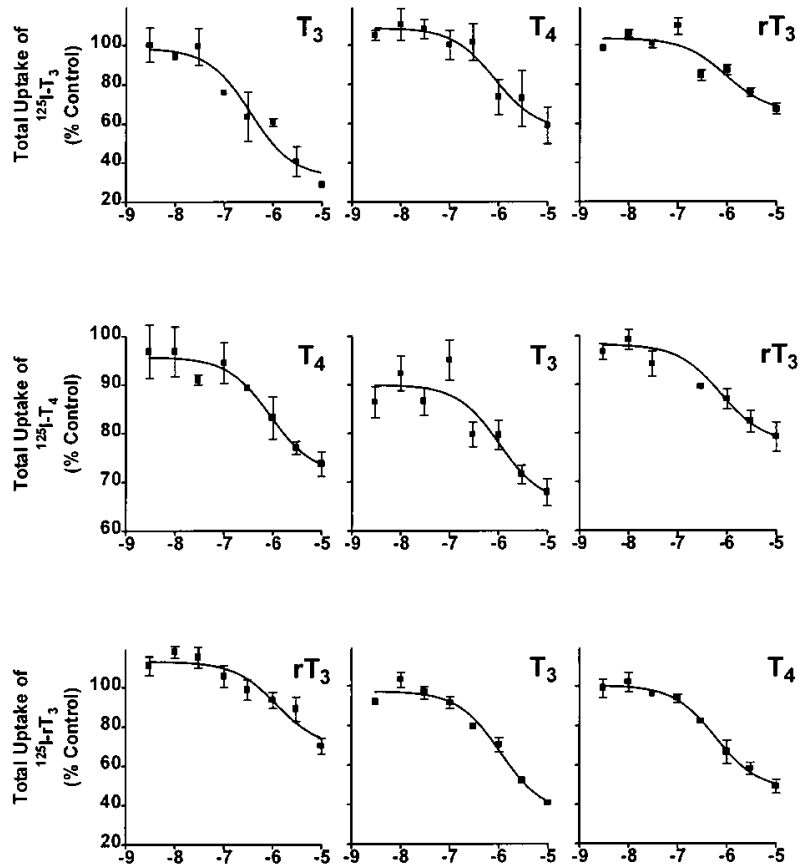

Log [thyroid hormone] (M)

Figure 4 Interaction between uptake systems for thyroid hormones in JAR cells. Cells were incubated for 2 min at $37^{\circ} \mathrm{C}$ with $30 \mathrm{pM}^{125} \mathrm{I}-\mathrm{T}_{3}, 50 \mathrm{pM}^{125} \mathrm{I}-\mathrm{T}_{4}$ or $100 \mathrm{pM}^{125} \mathrm{I}-\mathrm{rT}_{3}$ in the presence of increasing concentrations $(0-10 \mu \mathrm{M})$ of an appropriate unlabelled thyroid hormone analogue. Values are means \pm S.E.M. $(n=3-10)$.

uptake of $\mathrm{T}_{3}, \mathrm{~T}_{4}$ and $\mathrm{rT}_{3}$. It is also uncertain whether thyroid hormones enter and leave the cells by the same or different mechanisms. In this study, we further character- ised thyroid hormone transport processes in JAR cells by examining interactions between uptake and efflux of $\mathrm{T}_{3}$, $\mathrm{T}_{4}$ and $\mathrm{rT}_{3}$ and compounds which interfere with uptake of thyroid hormones in other types of cells. We chose the cytotrophoblast-derived cell line, JAR, as a convenient model of the human trophoblast. Although these cells are transformed and may exhibit characteristics different from those found in normal trophoblast cells, they do retain membrane transport processes for taurine and $\mathrm{T}_{3}$ which are kinetically identical to those of normal trophoblast (Kulanthaivel et al. 1991, Mitchell et al. 1992a). We previously found no significant deiodination of either ${ }^{125} \mathrm{I}_{-} \mathrm{T}_{3}$ (Mitchell et al. 1992a), ${ }^{125} \mathrm{I}_{-} \mathrm{T}_{4}$ (Mitchell et al. 1995) or ${ }^{125} \mathrm{I}-\mathrm{rT}_{3}$ (Mitchell et al. 1998) under the experimental conditions used in the present study. The lack of deiodination by these cells makes them a useful model for study of membrane transport of thyroid hormones.

We studied the effects of unlabelled thyroid hormones on uptake of ${ }^{125} \mathrm{I}_{-} \mathrm{T}_{3},{ }^{125} \mathrm{I}-\mathrm{T}_{4}$ and ${ }^{125} \mathrm{I}_{-} \mathrm{rT}_{3}$ in JAR cells to examine the specificity of thyroid hormone uptake processes. Of the thyroid hormones tested, $\mathrm{L}_{-} \mathrm{T}_{3}(10 \mu \mathrm{M})$ was the most effective inhibitor of ${ }^{125} \mathrm{I}_{-} \mathrm{T}_{3}$ uptake, with inhibition of around $70 \%$ of total uptake. The transport mechanism for ${ }^{125} \mathrm{I}_{-} \mathrm{T}_{3}$ was, however, not specific for $\mathrm{L}-\mathrm{T}_{3}$ as it also interacted with $\mathrm{L}_{-} \mathrm{T}_{4}, \operatorname{Trp}$ and $\mathrm{rT}_{3}$. These latter compounds were not as effective in inhibiting ${ }^{125} \mathrm{I}_{-} \mathrm{T}_{3}$ uptake as $\mathrm{L}-\mathrm{T}_{3}$ itself and $\mathrm{L}-\mathrm{T}_{4}$ inhibited only about $30 \%$ of total $\mathrm{T}_{3}$ uptake. Similarly, uptake of ${ }^{125} \mathrm{I}_{-} \mathrm{T}_{4}$ was not only inhibited by $\mathrm{L}-\mathrm{T}_{4}$ (around $30 \%$ ), but also by $\mathrm{L}^{-\mathrm{T}_{3}}$ and $\mathrm{rT}_{3}$ (both around 20\%). Although unlabelled $\mathrm{rT}_{3}$ inhibited around $30 \%$ of ${ }^{125} \mathrm{I}_{\mathrm{rT}} \mathrm{T}_{3}$ uptake, unlabelled $\mathrm{L}-\mathrm{T}_{4}$ and $\mathrm{L}-\mathrm{T}_{3}$ were more effective inhibitors of ${ }^{125} \mathrm{I}_{-} \mathrm{rT}_{3}$ uptake than $\mathrm{L}-\mathrm{rT}_{3}$, indicating that the uptake process was not specific for $\mathrm{rT}_{3}$.

Table 1 Kinetic parameters of uptake of ${ }^{125}$ I-labelled thyroid hormones and of inhibition of ${ }^{125} \mathrm{I}$-labelled thyroid hormone uptake by unlabelled thyroid hormones in JAR cells

\begin{tabular}{|c|c|c|c|c|}
\hline & Kinetic parameter & $\begin{array}{l}\text { Mean } \pm \text { S.E.M. } \\
\text { uptake }(\mu \mathrm{M})\end{array}$ & $n$ & $\boldsymbol{P}$ \\
\hline \multicolumn{5}{|l|}{ Transporters } \\
\hline \multirow[t]{4}{*}{$\mathrm{T}_{3}$ and $\mathrm{T}_{4}$} & $K_{\mathrm{m}}$ for $\mathrm{T}_{3}$ uptake & $0 \cdot 39 \pm 0 \cdot 17$ & 5 & \multirow{2}{*}{\} 0.095} \\
\hline & $K_{\mathrm{i}}$ for inhibition of $\mathrm{T}_{4}$ uptake by $\mathrm{T}_{3}$ & $1 \cdot 10 \pm 0 \cdot 27$ & 7 & \\
\hline & $K_{\mathrm{m}}$ for $\mathrm{T}_{4}$ uptake & $0 \cdot 75 \pm 0 \cdot 16$ & 3 & \multirow{2}{*}{\} 0.686} \\
\hline & $K_{\mathrm{i}}$ for inhibition of $\mathrm{T}_{3}$ uptake by $\mathrm{T}_{4}$ & $1 \cdot 13 \pm 0 \cdot 74$ & 4 & \\
\hline \multirow[t]{4}{*}{$\mathrm{T}_{3}$ and $\mathrm{rT}_{3}$} & $K_{\mathrm{m}}$ for $\mathrm{T}_{3}$ uptake & $0 \cdot 39 \pm 0 \cdot 17$ & 5 & \multirow{2}{*}{\} 0.031} \\
\hline & $K_{\mathrm{i}}$ for inhibition of $\mathrm{rT}_{3}$ uptake by $\mathrm{T}_{3}$ & $1 \cdot 23 \pm 0 \cdot 29$ & 4 & \\
\hline & $K_{\mathrm{m}}$ for $\mathrm{rT}_{3}$ uptake & $3 \cdot 98 \pm 0 \cdot 55$ & 10 & \multirow{2}{*}{\} 0.003} \\
\hline & $K_{\mathrm{i}}$ for inhibition of $\mathrm{T}_{3}$ uptake by $\mathrm{rT}_{3}$ & $1 \cdot 55 \pm 0 \cdot 43$ & 9 & \\
\hline \multirow[t]{4}{*}{$\mathrm{T}_{4}$ and $\mathrm{rT}_{3}$} & $K_{\mathrm{m}}$ for $\mathrm{T}_{4}$ uptake & $0 \cdot 75 \pm 0 \cdot 16$ & 3 & \multirow{2}{*}{\} $0 \cdot 762$} \\
\hline & $K_{\mathrm{i}}$ for inhibition of $\mathrm{rT}_{3}$ uptake by $\mathrm{T}_{4}$ & $0 \cdot 66 \pm 0 \cdot 19$ & 4 & \\
\hline & $K_{\mathrm{m}}$ for $\mathrm{rT}_{3}$ uptake & $3 \cdot 98 \pm 0.55$ & 10 & \multirow{2}{*}{\} 0.001} \\
\hline & $K_{\mathrm{i}}$ for inhibition of $\mathrm{T}_{4}$ uptake by $\mathrm{rT}_{3}$ & $1 \cdot 05 \pm 0 \cdot 34$ & 8 & \\
\hline
\end{tabular}


We examined the specificity of thyroid hormone uptake processes in JAR cells by looking at the effects on saturable uptake of ${ }^{125} \mathrm{I}_{-} \mathrm{T}_{3},{ }^{125} \mathrm{I}_{-} \mathrm{T}_{4}$ and ${ }^{125} \mathrm{I}^{-} \mathrm{rT}_{3}$ of a series of compounds which have been reported to interfere with thyroid hormone uptake in other cells. These included mefenamic acid (a non-steroidal anti-inflammatory drug which inhibits $\mathrm{T}_{3}$ uptake into cultured rat hepatoma cells (Topliss et al. 1989)), and verapamil, nifedipine and nitrendipine (voltage-dependent calcium channel blockers of the dihydropyridine class which inhibit $\mathrm{T}_{3}$ uptake in rat hepatoma and myoblast cell lines (Topliss et al. 1993)). All inhibited saturable $\mathrm{T}_{3}$ uptake in JAR cells by around 50-70\%, but had no effect on $\mathrm{T}_{4}$ uptake, suggesting that $\mathrm{T}_{3}$ was transported by two systems, only one of which interacted with $\mathrm{T}_{4}$. In addition, verapamil and nifedipine also inhibited $\mathrm{rT}_{3}$ uptake by around $30 \%$. The inhibition of $\mathrm{T}_{3}$ and $\mathrm{rT}_{3}$ uptake by calcium channel blockers raises the possibility that $\mathrm{T}_{3}$ and $\mathrm{rT}_{3}$ uptake in JAR cells occurs by a calcium-related mechanism, as was found for $T_{3}$ uptake in a rat hepatoma and myoblast cell lines (Topliss et al. 1993).

$\mathrm{T}_{3}, \mathrm{~T}_{4}$ and $\mathrm{rT}_{3}$ all inhibited uptake of the radiolabelled hormones in a dose-dependent way (Fig. 4) with the calculated $K_{\mathrm{i}}$ within the micromolar range (Table 1). $\mathrm{L}-\mathrm{T}_{3}$ and $\mathrm{L}-\mathrm{T}_{4}$ inhibited uptake of ${ }^{125} \mathrm{I}_{-} \mathrm{T}_{4}$ with similar potencies, but $\mathrm{L}-\mathrm{T}_{4}$ was less effective in inhibiting uptake of ${ }^{125} \mathrm{I}_{-} \mathrm{T}_{3}$ than was $\mathrm{L}-\mathrm{T}_{3}$ itself. Assuming that $\mathrm{L}-\mathrm{T}_{4}$ was interacting with the saturable component of ${ }^{125} \mathrm{I}_{-} \mathrm{T}_{3}$ uptake (which accounts for around $70 \%$ of total uptake of $\left.{ }^{125} \mathrm{I}_{-} \mathrm{T}_{3}\right), \quad \mathrm{L}-\mathrm{T}_{4}$ inhibited less than half of the saturable uptake of ${ }^{125} \mathrm{I}_{-} \mathrm{T}_{3}$. This was similar to the dose-dependent $\left(K_{\mathrm{i}}=2.9 \mathrm{mM}\right)$ but incomplete inhibition (around 75\%) of $\mathrm{T}_{3}$ uptake by $\operatorname{Trp}$ reported previously (Mitchell et al. 1994). These results suggest that uptake of thyroid hormones in JAR cells may be mediated by two transporters: an iodothyronine transporter which takes up $\mathrm{T}_{4}, \mathrm{~T}_{3}$ and $\mathrm{rT}_{3}$ and is not inhibited by Trp, and another transporter which takes up $\mathrm{T}_{3}$, is inhibited by Trp, and is likely to be an aromatic amino acid transporter. The iodothyronine transporter which takes up $\mathrm{T}_{3}, \mathrm{~T}_{4}$ and $\mathrm{rT}_{3}$ may be similar to the thyroid hormone transporter described in rat anterior pituitary cells (Everts et al. 1995).

There are conflicting reports as to whether $\mathrm{T}_{3}, \mathrm{rT}_{3}$ and $\mathrm{T}_{4}$ are transported by the same or different carriers in non-placental tissues. In liver, $\mathrm{T}_{3}$ and $\mathrm{T}_{4}$ uptake has been reported to be mediated by different transporters (Krenning et al. 1981), or the same carrier system (Blondeau et al. 1988). In rat anterior pituitary cells, $\mathrm{rT}_{3}, \mathrm{~T}_{4}$ and $\mathrm{T}_{3}$ share the same transporter (Everts et al. 1994), while in rat hepatocytes $r_{3}$ and $T_{4}$ share the same transporter, which is different from that for $\mathrm{T}_{3}$ (Krenning et al. 1982). Recent evidence from serum tracer kinetic studies in humans suggests that the liver and other rapidly equilibrating tissues possess separate transport processes for $\mathrm{T}_{3}, \mathrm{~T}_{4}$ and $\mathrm{rT}_{3}$ (Kaptein 1997).
There have been few studies of thyroid hormone efflux from cells. $T_{3}$ appears to diffuse passively from rat hepatocytes (Hennemann et al. 1984). Efflux of $\mathrm{T}_{3}$ from rat erythrocytes is inhibited by excess $\mathrm{T}_{3}(10 \mu \mathrm{M})$ (Osty et al. 1990b, Samson et al. 1992) or $5 \mathrm{mM}$ Trp (Zhou et al. 1992) in the external medium, suggesting a saturable membrane carrier subject to trans-inhibition. Efflux of $\mathrm{T}_{3}$ but not of $\mathrm{T}_{4}$ from human erythrocytes is also saturable (Osty et al. 1990a). There is evidence in hepatocytes that $\mathrm{T}_{3}$ uptake is energy dependent, while $\mathrm{T}_{3}$ efflux is not, suggesting that membrane carriers mediating uptake and efflux of thyroid hormones may be distinct (Hennemann et al. 1984). It is not known whether similar carriers are present in the intact liver in vivo.

We examined the effect of thyroid hormone analogues on efflux of $T_{3}$ and $T_{4}$ in JAR cells to investigate whether release of $T_{3}$ and $T_{4}$ is mediated by the same or different mechanisms. $\mathrm{L}-\mathrm{T}_{3}(33 \%), \mathrm{L}-\mathrm{T}_{4}(23 \%)$, nitrendipine $(26 \%)$ and $\operatorname{Trp}(30 \%)$ inhibited efflux of ${ }^{125} \mathrm{I}_{-} \mathrm{T}_{3}$. Efflux of $\mathrm{T}_{4}$ was, in contrast, not affected by any of the compounds tested, suggesting that in these cells different mechanisms mediated the release of ${ }^{125} \mathrm{I}-\mathrm{T}_{4}$ and ${ }^{125} \mathrm{I}_{-} \mathrm{T}_{3}$. These results are similar to those described in human erythrocytes, where $T_{3}$ efflux is subject to trans-inhibition while $T_{4}$ efflux is not. It has been proposed that $\mathrm{T}_{3}$ efflux is mediated by facilitated diffusion, while $\mathrm{T}_{4}$ efflux results from passive diffusion (Osty et al. 1990a). Efflux of $\mathrm{rT}_{3}$ in JAR cells was also not saturable.

The results of the present study indicated that in JAR cells both the uptake and release of $T_{3}$ occur by saturable processes that exhibit similar specificities for the other thyroid hormones. This suggests that, the same transporter mediates uptake and efflux of $\mathrm{T}_{3}$. Uptake of $\mathrm{T}_{4}$ was also saturable but appeared to proceed by a mechanism distinct from that for $\mathrm{T}_{3}$. Efflux of $\mathrm{rT}_{3}$ and $\mathrm{T}_{4}$, in contrast to efflux of $T_{3}$, was not saturable. This suggests that, in JAR cells, different transporters mediate uptake and release of $\mathrm{T}_{4}$. As $\mathrm{T}_{3}$, but not $\mathrm{T}_{4}$ or $\mathrm{rT}_{3}$, efflux was saturable, it is unlikely that in JAR cells $\mathrm{T}_{3}, \mathrm{rT}_{3}$ and $\mathrm{T}_{4}$ exit by a common carrier.

In liver, inhibition of membrane transport of $\mathrm{T}_{3}$ (which has a $K_{\mathrm{m}}$ similar to values described by us in this and previous studies) significantly decreases intracellular deiodination of the hormone (Hennemann et al. 1986). Although, as yet, only $\mathrm{T}_{3}$ membrane transport has been demonstrated in normal trophoblast, we postulate that in the placenta cell membrane transport may regulate access of extracellular hormones to intracellular deiodinases, thereby modulating placental thyroid hormone transfer.

In conclusion, we have demonstrated the presence of saturable, stereospecific membrane transport processes mediating both the uptake and efflux of ${ }^{125} \mathrm{I}_{-} \mathrm{T}_{3}$ in JAR cells. In contrast, the uptake, but not the efflux, of ${ }^{125} \mathrm{I}_{-} \mathrm{T}_{4}$ and ${ }^{125} \mathrm{I}_{\mathrm{rT}} \mathrm{T}_{3}$ was saturable and stereospecific, indicating that uptake and efflux of $\mathrm{T}_{4}$ and $\mathrm{rT}_{3}$ in JAR cells proceeded via different mechanisms. An iodothyronine transporter mediates uptake of $\mathrm{T}_{4}$ and $\mathrm{rT}_{3}$, and contributes 
to uptake of $\mathrm{T}_{3}$. Efflux of $\mathrm{T}_{4}$ and $\mathrm{rT}_{3}$, which is not saturable, may occur by passive diffusion, though it could occur via the iodothyronine transporter if this transporter is not subject to trans-inhibition by substrate. In addition to the iodothyronine transporter, $\mathrm{T}_{3}$ may also be transported in JAR cells by a carrier which is inhibited by Trp and dihydropyridines, does not interact with $\mathrm{T}_{4}$ and $\mathrm{rT}_{3}$, and is likely to be an aromatic amino acid transporter.

\section{Acknowledgements}

We thank Mrs Kym Doyle for technical assistance with the experiments. This work was supported by a Project Grant from the National Health and Medical Research Council of Australia.

\section{References}

Blondeau J-P, Osty J \& Francon J 1988 Characterization of the thyroid hormone transport system of isolated hepatocytes. Journal of Biological Chemistry 263 2685-2692.

Everts ME, Lim CF, Moerings EP, Docter R, Visser TJ, de Jong M, Krenning EP \& Hennemann G 1995 Effects of a furan fatty acid and indoxyl sulfate on thyroid hormone uptake in cultured anterior pituitary cells. American Journal of Physiology 268 E974-E979.

Everts ME, Docter R, Moerings EP, van Koetsveld PM, Visser PJ, de Jong M, Krenning EP \& Hennemann G 1994 Uptake of thyroxine in cultured anterior pituitary cells of euthyroid rats. Endocrinology $1342490-2497$.

Hennemann G, Krenning EP, Bernard B, Huvers F, Mol J, Docter R \& Visser TJ 1984 Regulation of influx and efflux of thyroid hormones in rat hepatocytes: possible physiologic significance of the plasma membrane in the regulation of thyroid hormone activity. Hormone and Metabolic Research (Suppl) 14 1-5.

Hennemann G, Krenning EP, Polhuys M, Mol JA, Bernard BF, Visser TJ \& Docter R 1986 Carrier-mediated transport of thyroid hormone into rat hepatocytes is rate-limiting in total cellular uptake and metabolism. Endocrinology 119 1870-1872.

Kaptein EM 1997 Hormone-specific alterations of $T_{4} T_{3}$ and reverse $\mathrm{T}_{3}$ metabolism with reent ethanol abstinence in humans. American Journal of Physiology 272 E191-E200.

Kragie L 1994 Membrane iodothyronine transporters part I: review of physiology. Endocrine Research 20 319-341.

Kragie L 1996 Membrane iodothyronine transporters part II: review of protein biochemistry. Endocrine Research 22 95-119.

Krenning EP, Docter R, Bernard HF, Visser TJ \& Hennemann G 1981 Characteristics of active transport of thyroid hormone into rat hepatocytes. Biochimica et Biophysica Acta 676 314-320.

Krenning EP, Docter R, Bernard HF, Visser TJ \& Hennemann G 1982 Decreased transport of thyroxine $\left(\mathrm{T}_{4}\right), 3,3^{\prime}, 5$-triiodothyronine
$\left(\mathrm{T}_{3}\right)$ and $3,3^{\prime}, 5^{\prime}$-triiodothyronine $\left(\mathrm{rT}_{3}\right)$ into rat hepatocytes in primary culture due to a decrease in ATP content and various drugs. FEBS Letters 140 229-233.

Kulanthaivel P, Cool DR, Ramamoorthy S, Mahesh VB, Leibach FH \& Ganapathy V 1991 Transport of taurine and its regulation by protein kinase $\mathrm{C}$ in the JAR human placental choriocarcinoma cell line. Biochemical Journal 227 53-58.

Mitchell AM, Manley SW \& Mortimer RH 1992a Membrane transport of thyroid hormone in the human choriocarcinoma cell line JAR. Molecular and Cellular Endocrinology 87 139-145.

Mitchell AM, Manley SW \& Mortimer RH $1992 b$ Uptake of L-triiodothyronine by human cultured trophoblast cells. Journal of Endocrinology 133 483-486.

Mitchell AM, Manley SW \& Mortimer RH 1994 Interactions between transport of triiodothyronine and tryptophan in JAR cells. Molecular and Cellular Endocrinology 101 203-210.

Mitchell AM, Manley SW \& Mortimer RH 1995 Uptake of thyroxine in the human choriocarcinoma cell line JAR. Journal of Endocrinology 146 233-238.

Mitchell AM, Manley SW, Rowan KA \& Mortimer RH 1998 Uptake of reverse $\mathrm{T}_{3}$ in the human choriocarcinoma cell line, JAR. Placenta 19 (In Press).

Osty J, Valensi P, Samson M, Francon J \& Blondeau J-P 1990a Transport of thyroid hormones by human erythrocytes: kinetic characterization in adults and newborns. Journal of Clinical Endocrinology and Metabolism 71 1589-1595.

Osty J, Zhou Y, Chantoux F, Francon J \& Blondeau J-P 19906 The triiodothyronine carrier of rat erythrocytes: asymmetry and mechanisms of trans-inhibition. Biochimica et Biophysica Acta 1051 $46-51$.

Samson M, Osty J, Francon J \& Blondeau J-P 1992 Triiodothyronine binding sites in the rat erythrocyte membrane: involvement in triiodothyronine transport and relation to the tryptophan transport system T. Biochimica et Biophysica Acta 1108 91-98.

Topliss DJ, Kolliniatis E, Barlow JW, Lim CF \& Stockigt JR 1989 Uptake of 3,5 3'-triiodothyronine by cultured rat hepatoma cells is inhibitable by nonbile acid cholephils, diphenylhydantoin, and non-steroidal antiinflammatory drugs. Endocrinology 124 980-986.

Topliss DJ, Scholtz GH, Kolliniatis E, Barlow JW \& Stockigt JR 1993 Influence of calmodulin antagonists and calcium channel blockers on triiodothyronine uptake by rat hepatoma and myoblast cell lines. Metabolism 42 376-380.

Vulsma T, Gons MH \& de Vijder JJM 1989 Maternal-fetal transfer of thyroxine in congenital hypothyroidism due to a total organification defect of thyroid agenesis. New England Journal of Medicine 321 13-46.

Zhou Y, Samson M, Francon J \& Blondeau J-P 1992 Thyroid hormone concentrative uptake in rat erythrocytes. Biochemical Journal 281 81-86.

Received 14 August 1998

Accepted 13 November 1998 